NASA/TM-2000-209912

\title{
Spacecraft Impacts with Advanced Power and Electric Propulsion
}

Lee S. Mason and Steven R. Oleson

Glenn Research Center, Cleveland, Ohio 
Since its founding, NASA has been dedicated to the advancement of aeronautics and space science. The NASA Scientific and Technical Information (STI) Program Office plays a key part in helping NASA maintain this important role.

The NASA STI Program Office is operated by Langley Research Center, the Lead Center for NASA's scientific and technical information. The NASA STI Program Office provides access to the NASA STI Database, the largest collection of aeronautical and space science STI in the world. The Program Office is also NASA's institutional mechanism for disseminating the results of its research and development activities. These results are published by NASA in the NASA STI Report Series, which includes the following report types:

- TECHNICAL PUBLICATION. Reports of completed research or a major significant phase of research that present the results of NASA programs and include extensive data or theoretical analysis. Includes compilations of significant scientific and technical data and information deemed to be of continuing reference value. NASA's counterpart of peerreviewed formal professional papers but has less stringent limitations on manuscript length and extent of graphic presentations.

- TECHNICAL MEMORANDUM. Scientific and technical findings that are preliminary or of specialized interest, e.g., quick release reports, working papers, and bibliographies that contain minimal annotation. Does not contain extensive analysis.

- CONTRACTOR REPORT. Scientific and technical findings by NASA-sponsored contractors and grantees.
- CONFERENCE PUBLICATION. Collected papers from scientific and technical conferences, symposia, seminars, or other meetings sponsored or cosponsored by NASA.

- SPECIAL PUBLICATION. Scientific, technical, or historical information from NASA programs, projects, and missions, often concerned with subjects having substantial public interest.

- TECHNICAL TRANSLATION. Englishlanguage translations of foreign scientific and technical material pertinent to NASA's mission.

Specialized services that complement the STI Program Office's diverse offerings include creating custom thesauri, building customized data bases, organizing and publishing research results ... even providing videos.

For more information about the NASA STI Program Office, see the following:

- Access the NASA STI Program Home Page at http://www.sti.nasa.gov

- E-mail your question via the Internet to help@sti.nasa.gov

- Fax your question to the NASA Access Help Desk at (301) 621-0134

- Telephone the NASA Access Help Desk at (301) 621-0390

- Write to:

NASA Access Help Desk

NASA Center for AeroSpace Information 7121 Standard Drive

Hanover, MD 21076 
NASA/TM-2000-209912

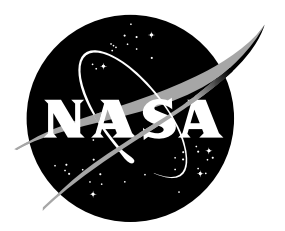

\section{Spacecraft Impacts with Advanced Power and Electric Propulsion}

Lee S. Mason and Steven R. Oleson

Glenn Research Center, Cleveland, Ohio

Prepared for the

2000 Aerospace Conference

sponsored by the Institute of Electrical and Electronics Engineers

Big Sky, Montana, March 18-25, 2000

National Aeronautics and

Space Administration

Glenn Research Center 
This report contains preliminary findings, subject to revision as analysis proceeds.

a

Available from

NASA Center for Aerospace Information 7121 Standard Drive

Hanover, MD 21076

Price Code: A03
National Technical Information Service 5285 Port Royal Road Springfield, VA 22100 Price Code: A03 


\title{
Spacecraft Impacts with Advanced Power and Electric Propulsion
}

\author{
Lee S. Mason and Steven R. Oleson \\ National Aeronautics and Space Administration \\ Glenn Research Center \\ Cleveland, Ohio 44135 \\ (216) 977-7106, (216) 977-7426 \\ Lee.Mason@grc.nasa.gov, Steven.Oleson@grc.nasa.gov
}

\begin{abstract}
A study was performed to assess the benefits of advanced power and electric propulsion systems for various space missions. Advanced power technologies that were considered included multi-band gap and thin-film solar arrays, lithium batteries, and flywheels. Electric propulsion options included Hall effect thrusters and Ion thrusters. Several mission case studies were selected as representative of future applications for advanced power and propulsion systems. These included a low altitude Earth science satellite, a LEO communications constellation, a GEO military surveillance satellite, and a Mercury planetary mission. The study process entailed identification of overall mission performance using state-of-the-art power and propulsion technology, enhancements made possible with either power or electric propulsion advances individually, and the collective benefits realized when advanced power and electric propulsion are combined. Impacts to the overall spacecraft included increased payload, longer operational life, expanded operations and launch vehicle class stepdowns.
\end{abstract}

\section{INTRODUCTION}

Separately, advanced power systems and electric propulsion can offer significant benefits for future spacecraft. Ongoing developments in power technology are aimed at increasing solar cell efficiency, reducing solar array mass, and improving battery energy density. These advances will provide at least a two-fold improvement in the system power-to-weight ratio. Concurrently, electric thrusters are being developed for use on numerous Earth orbital and space science missions. The high specific impulse achievable with Ion and Hall effect thrusters reduces the fuel loading by more than a factor of two over conventional chemical thrusters.

When advanced power and electric propulsion are combined, dramatic benefits may be realized due to the synergism of the two technologies. Potential impacts to the spacecraft include increased payload, longer operational life, expanded operations, and launch vehicle class stepdowns. Savings in power system mass brought about by advanced technology permit increases in the satellite power level. The higher power level enables the use of higher thrust and higher specific impulse electric thrusters. The resulting propellant mass savings can be utilized in several different ways:

- Allow additional mass for payload.

- Allow additional mass for the power system, which provides further improvements to the electric propulsion system and/or functionality to the payload.

- Reduce the overall spacecraft mass to permit use of a smaller, less-expensive launch vehicle.

- Add additional propellant to extend mission life (stationkeeping) or enhance operational capability (repositions).

Since the operation of the propulsion system and the payload (science instruments, communications antennae, etc.) do not usually coincide, full use of the power system is available to both ${ }^{1}$.

An analytical study was performed to quantify the potential benefits of advanced power and electric propulsion. The study examined the impacts resulting from each technology individually, and both technologies collectively. The analysis accounted for the iterative nature of the concept: better power allows power level increases, leading to better propulsion, allowing more payload, which in turn requires more power. Several case studies were selected for assessment including a NASA Earth Science satellite (Tropical Rainfall Measurement Mission, or TRMM), a commercial Low Earth Orbit (LEO) communications constellation (Globalstar), a Geosynchronous Earth Orbit (GEO) military surveillance satellite (Space Based Infrared Systems-High, or SBIRS-High), and a NASA solar system exploration spacecraft (Mercury Orbiter). The missions were deemed representative of the wide range of possible applications for future power and propulsion systems. In all cases, the analytical results affirmed the projected benefits possible with advanced power and electric propulsion.

\footnotetext{
${ }^{1}$ This assertion is not always true since stationkeeping and attitude control maneuvers may occur during payload operations. If electric propulsion is used, these relatively low power operations must be accounted for in the power budget, or additional power must be allocated specifically for the thrusters.
} 


\section{ADVANCED POWER TECHNOLOGY}

Significant technology advances are anticipated in both power conversion and energy storage systems in the next several years. These advances are aimed at reducing the weight, increasing the life, and decreasing the costs of power system components. Technology development programs are presently in place to improve the state-of-theart (SOA) in crystalline solar photovoltaic (PV) cells and arrays, nickel-based batteries, and power management and distribution (PMAD) systems. New technology efforts have also been initiated to develop thin-film solar arrays, lithium batteries, and flywheel energy storage systems.

The performance projections stated in this paper are based on recent discussions with technology managers and are consistent with the specified references. The values are intended to represent the future goals of the technology development effort. Some variation in these values is expected depending on the particular mission application, the power system requirements, as well as the mission timeframe.

The SOA in PV arrays is single junction gallium arsenide $(\mathrm{GaAs})$ solar cells on germanium $(\mathrm{Ge})$ substrates with rigid, metallic supporting structure. These cells are approximately $19 \%$ efficient (Beginning-Of-Life, BOL) and the array specific power is about $40 \mathrm{~W} / \mathrm{kg}$. Traditional silicon $(\mathrm{Si})$ solar arrays are still occasionally used for low power applications to reduce cell costs. The projected efficiency and array specific power for several near term PV candidate technologies are presented in Table 1. Efficiency increases are expected based on the development of multi-junction cell technology [1]. Multi-junction cells, also called multiband gap cells or cascade cells, utilize several layers of semiconductor materials to capture and convert a greater portion of the solar spectrum. Dual junction cells using GaInP/GaAs technology will improve the BOL cell efficiency to $23 \%$ and the addition of $\mathrm{Ge}$ as an active third junction will increase efficiency to $26 \%$. The next generation of multi-band gap solar cells will utilize four junctions, with optimized band-gaps, to provide cell efficiencies approaching $35 \% \mathrm{BOL}$. The reduced array area resulting from the cell efficiency increases, combined with the application of lightweight composite or inflatable structures, is expected to provide corresponding improvements in array specific power. The $100 \mathrm{~W} / \mathrm{kg}$ array specific power projected for the four junction solar arrays is a $2.5 \mathrm{x}$ increase from the SOA. Concentrator versions of multi-band gap solar arrays are projected to provide similar performance while reducing solar cell costs by decreasing the cell area according to the concentration ratio of the reflecting lens [2].

Thin-film solar arrays are expected to provide even higher array specific power, albeit at lower cell efficiency [1]. Amorphous silicon (a-Si) array technology is in wide use in terrestrial applications. Space versions are expected to offer $10 \% \mathrm{BOL}$ cell efficiency and $100 \mathrm{~W} / \mathrm{kg}$ array specific power. Another candidate thin-film technology, $\mathrm{CuInGaSe}_{2}$ (CIGS) projects an array specific power of $200 \mathrm{~W} / \mathrm{kg}$ and a cell efficiency of $15 \%$ BOL. Additional benefits of thinfilm arrays may include increased cell packing factors and improved radiation tolerance. Considerable array blanket cost savings may also be achievable with thin-film technology due to the potential for mass production.

Table 1. Solar Array Technologies

\begin{tabular}{|l|c|c|}
\hline Cell Type & $\begin{array}{c}\text { BOL } \\
\text { Efficiency } \\
(\%)\end{array}$ & $\begin{array}{c}\text { Specific } \\
\text { Power } \\
(\mathrm{W} / \mathrm{kg})\end{array}$ \\
\hline $\mathrm{Si}$ & 10 & 25 \\
\hline $\mathrm{GaAs}$ & 19 & 40 \\
\hline $\mathrm{GaInP} / \mathrm{GaAs}(2 \mathrm{~J})$ & 23 & 60 \\
\hline $\mathrm{GaInP} / \mathrm{GaAs} / \mathrm{Ge}(3 \mathrm{~J})$ & 26 & 80 \\
\hline InGaAlP/GaAs/InGaAs/Ge (4J) & 35 & 100 \\
\hline Amorphous Si & 10 & 100 \\
\hline $\mathrm{CuInGaSe}_{2}$ (CIGS) & 15 & 200 \\
\hline
\end{tabular}

The present SOA in rechargable battery technology is common pressure vessel (CPV) nickel hydrogen $\left(\mathrm{NiH}_{2}\right)$ providing $35 \mathrm{Whr} / \mathrm{kg}$ energy density and 35\% depth-ofdischarge (DOD) for LEO and 70\% DOD for GEO ${ }^{2}$. Some satellites still utilize nickel cadium (NiCd) batteries despite lesser performance, due to cost savings. Table 2 summarizes the projected improvement in energy density and DOD for a number of advanced energy storage technologies including flywheels. Bipolar nickel metal hydride $(\mathrm{NiMH})$ is the next generation of nickel-based technology offering greater than $2 x$ increase in energy density [3]. Lithium technology represents the next major advancement in batteries. Nearer term lithium-ion batteries with liquid electrolyte, promise energy densities approaching $100 \mathrm{Whr} / \mathrm{kg}$ or more. Farther term, solid polymer electrolyte lithium batteries project energy densities of at least $175 \mathrm{Whr} / \mathrm{kg}$ and DOD's of $50 \%$ for LEO and $80 \%$ for GEO [4].

Table 2. Energy Storage Technologies

\begin{tabular}{|l|c|c|c|}
\hline Technology & $\begin{array}{c}\text { Energy } \\
\text { Density* } \\
(\text { Whr/kg) }\end{array}$ & $\begin{array}{c}\text { LEO DOD } \\
(\%)\end{array}$ & $\begin{array}{c}\text { GEO DOD } \\
(\%)\end{array}$ \\
\hline NiCd & 25 & 25 & 60 \\
\hline CPV NiH2 & 35 & 35 & 70 \\
\hline Bipolar NiMH & 80 & 40 & 60 \\
\hline Li-ion (Liquid) & 85 & 40 & 60 \\
\hline Solid Li Polymer & 175 & 50 & 80 \\
\hline Flywheels & 44 & 89 & 89 \\
\hline
\end{tabular}

* Based on $100 \%$ DOD.

Aerospace batteries are penalized by inefficiencies in charging, storing, and discharging energy as well as limitations imposed by depth-of-discharge. Flywheel energy storage, as shown in Figure 1, offers the potential to eliminate or reduce these inefficiencies, thus reducing the required storage capacity as well as the size of the power generation system. A flight demonstration of a flywheel

\footnotetext{
${ }^{2}$ The difference in DOD is based on the number of charge/discharge cycles required for design life operation of the batteries. LEO missions typically have over 5000 cycles per year, whereas GEO missions may only have several hundred cycles per year.
} 
energy storage system is planned for the International Space Station in 2003. Flywheels are particularly suited to LEO applications since they are not subjected to the same low depth-of-discharge constraints as a battery in order to survive the large number of charge/discharge cycles. Energy density for flywheels with composite rotors is projected at $44 \mathrm{Whr} / \mathrm{kg}$. An additional advantage is the potential combined use of flywheels for both energy storage and spacecraft attitude control, although this was not considered in the study [5].

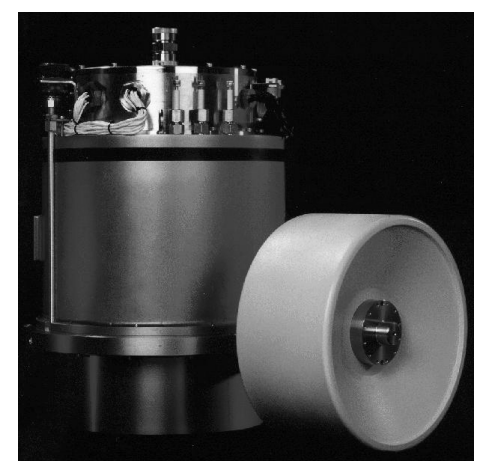

Figure 1. Flywheel Energy Storage

PMAD systems include the power electronics to regulate spacecraft bus voltage, the control electronics to maintain power system functionality, and the transmission cabling to distribute power across the various loads. The key performance metrics are efficiency and specific power. Today's PMAD systems are $80 \%$ to $85 \%$ efficient and about $50 \mathrm{~W} / \mathrm{kg}$. Future projections for PMAD systems promise efficiencies of greater than $90 \%$ and specific power levels of $250 \mathrm{~W} / \mathrm{kg}$.

\section{ELECTRIC PROPULSION TECHNOLOGY}

Electric propulsion technologies, once only a laboratory curiosity, are now taking their place as space propulsion devices. Two electrostatic devices, the Ion thruster and the Hall effect thruster, have been put into use for both commercial and space science applications. The $2.3 \mathrm{~kW}$ NSTAR thruster, shown in Figure 2, has already propelled the NASA Deep Space 1 spacecraft to an asteroid encounter and an extended mission is being considered to perform flybys of two comets [6]. Hughes is using a 500 watt class XIPS-13 Ion thruster for GEO satellite north-south stationkeeping (NSSK). Russian Hall thrusters, in the 500 $\mathrm{W}$ to $1500 \mathrm{~W}$ range, have already been operated in space for both orbit maintenance and NSSK applications [7]. Figure 3 is a photograph of a $4.5 \mathrm{~kW}$ Hall effect thruster planned for a future flight experiment on a Russian Express Satellite. The recent successful space demonstrations of electric thrusters affirm that these technologies are now ready to provide primary on-board propulsion for the next generation of spacecraft.

The primary advantage of electric propulsion systems is their low rate of fuel consumption, also termed high specific impulse (Isp). While chemical thrusters range in Isp from
100 to 450 seconds, electrostatic thrusters can provide between 1000 and 4000 seconds. This increase greatly reduces the amount of fuel needed to perform a propulsive maneuver. In most cases, the mission fuel requirements can be reduced by a factor of 2 to 10 . In some cases, electric propulsion systems become mission enabling when the fuel loading of the chemical system exceeds the payload capacity of the launch vehicle.

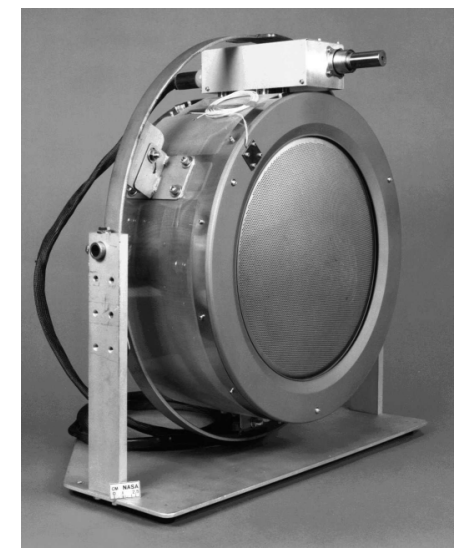

Figure 2. NSTAR Ion Thruster

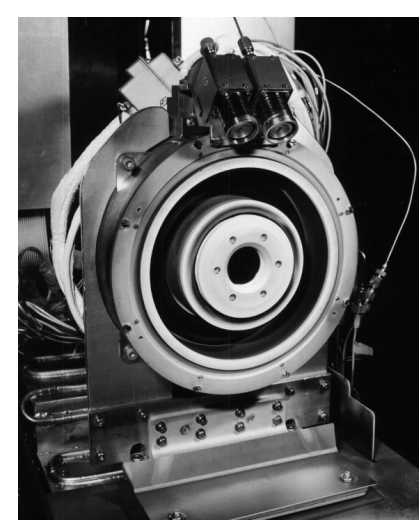

Figure 3. Express T-160 Hall Effect Thruster

In the past, the main drawbacks to electric propulsion were insufficient spacecraft power levels and long trip times. With today's spacecraft requiring greater amounts of electrical power to satisfy payload needs, electric propulsion has become a more viable option. Low Earth orbit science and telecommunications satellites are expected to extend into the 5 to $10 \mathrm{~kW}$ range. Geosynchronous communications satellites in the 20 to $30 \mathrm{~kW}$ range are already in the design stages. The fact that the payload is not usually in operation during orbit transfer maneuvers allows the electric propulsion system to function with full use of the available spacecraft power. The higher power level of future spacecraft will also contribute to more reasonable earth orbital trip times (on the order of months), and even faster trip times than conventional chemical systems for certain interplanetary missions.

For the missions analyzed in this paper, both Hall effect and Ion electrostatic systems were considered. The Hall thruster is predominantly used for Earth orbital missions since its Isp 
range of 1000 to 2500 seconds is better suited for the lower energy requirements of Earth orbit missions. The higher relative thrust produced by the Hall effect thruster also relates to shorter trip times than Ion systems for Earth orbital transfers. The Ion thruster, offering Isp in excess of 3000 seconds, is well suited for the higher energy planetary missions where fuel consumption is particularly critical.

Table 3 describes the performance and physical parameters of the thruster technologies considered in these analyses including the SOA chemical options. Mono-propellant systems using hydrazine $\left(\mathrm{N}_{2} \mathrm{H}_{4}\right)$ and bi-propellant systems using nitrogen tetroxide $\left(\mathrm{N}_{2} \mathrm{O}_{4}\right)$ mono-methyl hydrazine (NTO/MMH) are widely used for in-space propulsion. Specific impulse for the bi-prop chemical thruster varies depending on the application: orbit transfer or stationkeeping. In addition to Isp, the other key parameters used in sizing the electric propulsion systems are efficiency and thruster specific mass. For electrostatic propulsion devices, efficiency improves with increasing specific impulse and power level. Specific mass varies from about $20 \mathrm{~kg} / \mathrm{kW}$ at low power $(<1 \mathrm{~kW})$ to about $10 \mathrm{~kg} / \mathrm{kW}$ at $5 \mathrm{~kW}$ for the Hall thrusters. Performance projections are provided for both near and farther term Ion systems. Compared to Hall, the higher Isp Ion systems offer improved efficiency with slightly greater specific mass.

Table 3. Thruster Technologies

\begin{tabular}{|l|c|c|c|}
\hline Technology & $\begin{array}{c}\text { Specific } \\
\text { Impulse } \\
\text { (Isp, sec) }\end{array}$ & $\begin{array}{c}\text { Overall } \\
\text { Efficiency }\end{array}$ & $\begin{array}{c}\text { Specific } \\
\text { Mass } \\
(\mathrm{kg} / \mathrm{kW})\end{array}$ \\
\hline $\begin{array}{l}\text { Hydrazine } \\
\text { (Mono-Prop) }\end{array}$ & $220 \mathrm{~s}$ & - & - \\
\hline $\begin{array}{l}\text { NTO/MMH } \\
\text { (Bi-Prop) }\end{array}$ & $\begin{array}{c}330 \mathrm{~s} / 305 \mathrm{~s} \\
\mathrm{xfer} / \mathrm{NSSK}\end{array}$ & - & - \\
\hline $\begin{array}{l}\text { Hall Effect }(<1 \\
\mathrm{kW} \text { class) }\end{array}$ & $1600 \mathrm{~s}$ & $45 \%$ & 20 \\
\hline $\begin{array}{l}\text { Hall Effect }(1.5 \\
\mathrm{kW} \text { class) }\end{array}$ & $1600 \mathrm{~s}$ & $45 \%$ & 15 \\
\hline $\begin{array}{l}\text { Hall Effect }(5 \\
\mathrm{kW} \text { class })\end{array}$ & $1800 \mathrm{~s}$ & $52 \%$ & 10 \\
\hline $\begin{array}{l}\text { Ion }(5 \mathrm{~kW} \text { class, } \\
\text { near term) }\end{array}$ & $3600 \mathrm{~s}$ & $65 \%$ & 18 \\
\hline $\begin{array}{l}\text { Ion }(5 \mathrm{~kW} \text { class, } \\
\text { far term) }\end{array}$ & $4600 \mathrm{~s}$ & $70 \%$ & 14 \\
\hline
\end{tabular}

\section{ANALYTICAL PROCESS}

Separate power system and propulsion system analytical models, specifically developed for this study by the authors, were used in conjunction for the analyses. Mission requirements were determined from a variety of sources including open literature, personal conversations and internet searches. To the extent that they were available, the baseline power and propulsion technologies were identified from the reference information or selected based on the SOA as described previously.

In addition to the solar array figures-of-merit provided in Table 1, several other parameters were considered in sizing the solar arrays for this study. These included cell packing factor, array degradation factor (radiation, micrometeoroids, thermal fatigue, etc.), deployment/drive mass fraction, cell temperature, and array off-point angle. Other parameters used in sizing the energy storage systems beyond those discussed in Table 2 include volumetric density, roundtrip efficiency, charge/discharge efficiency, charge/discharge specific power, structure material density (aluminum, composite, etc.) and coldplate temperature. The coldplate temperature was used to size a waste heat radiator for the energy storage subsystem. Similarly, a PMAD coldplate temperature was used in order to size a radiator for the power electronics.

The analytical approach was devised to obtain an overall, performance optimized spacecraft. This was achieved by utilizing the mass savings from the advanced power or propulsion system for additional payload, increasing the power level proportionally to accommodate the larger payload, and then recalculating the power and propulsion system performance using the revised power level. This process was repeated until the payload mass change resulting from either power or propulsion improvements was zero. Electric propulsion performance was based strictly on solar array power, since no thrusting was assumed to occur during orbital eclipse.

The separate benefits of either power or propulsion were determined first. To quantify the benefits of advanced power alone, advanced components were selected to replace the baseline component set. This included replacement of the solar arrays, batteries, PMAD, and power system thermal control. The mass savings resulting from the advanced technologies were calculated, applied to the payload, and the power level was adjusted accordingly. This step was repeated until a convergence was obtained on power level and payload mass. The power system model was of sufficient fidelity to account for the economy-ofscale benefits at higher power levels, which also contributed to overall performance advantages.

A similar process was used in determining the individual benefits of electric propulsion. An electric propulsion system was identified to replace the baseline chemical propulsion system. The propulsion system and fuel mass savings were redirected to the payload and the power level was increased correspondingly. Corrections were made to the power system mass, while maintaining the baseline power technology assumptions, to account for the higher power level. The solar array power increase was also incorporated into a recalculation of the propulsion system and fuel mass, resulting in additional mass savings for the payload. As before, power level and payload mass calculations were repeated through convergence.

The spacecraft benefits with both advanced power and electric propulsion required a combination of the above steps. First, the power system was updated using advanced technology and the spacecraft power level was adjusted according to the payload mass increase. The new solar array power level was then used in determining the electric 
propulsion performance and associated fuel mass savings. Instead of applying all mass savings to the payload, several variations were explored. These included using the available mass for 1) a launch vehicle class step-down, 2) for added power to improve the electric propulsion performance, or 3) for more propellant to extend the mission life or permit additional maneuvers. For cases where the mission life was extended, the power and propulsion system assumptions were adjusted accordingly. In all cases, the power level, power system mass, and propulsion system mass were iterated until the payload mass change went to zero.

\section{MISSION CASE STUDIES}

Four mission case studies were chosen to serve as examples of how advanced power and electric propulsion can improve spacecraft performance. These missions were selected to provide a diverse range of requirements. The authors are not necessarily suggesting these specific missions should be modified, but rather that they represent the type of missions that would benefit by power and propulsion advances. In fact, two of the mission cases, TRMM and Globalstar have already been launched and are currently operating. The other two, SBIRS-High and Mercury Orbiter are still in the planning stages. In performing the studies, an effort was made to identify power and propulsion system features to enhance the overall mission. For example, the low altitude LEO mission, TRMM would benefit by low area solar arrays to reduce the spacecraft drag make-up requirement. The military surveillance mission, SBIRS-High becomes a more valuable asset if the propulsion system can accommodate a greater number of satellite repositions.

While many combinations of power system components could be considered for the mission studies, the actual systems presented in this paper were limited to a select few in order to simplify the presentation of the results. The selected technologies were determined to offer the greatest benefits to the various mission cases. These technologies included four junction multi-band gap solar arrays, flywheels (for LEO applications) and lithium polymer batteries (for GEO and interplanetary applications). However, the other advanced power technologies discussed in Section 2 would still offer benefits relative to the SOA technologies.

\section{Tropical Rainfall Measurement Mission (TRMM)}

TRMM is a low altitude, LEO Earth science mission that was launched in November 1997 on a Japanese H-II rocket [8]. An artist's rendering is provided in Figure 4. The satellite operates in a $350 \mathrm{~km}$ altitude orbit at $35^{\circ}$ inclination, resulting in a 91.5 minute orbit period and 36.5 minute maximum solar eclipse duration. The nominal spacecraft bus power is 1100 watts, and the energy storage requirement is $670 \mathrm{Whr}$. The baseline power system is GaAs solar arrays and NiCd batteries. The solar array power needed to meet the bus requirement and charge the batteries is $3.4 \mathrm{~kW}$ BOL. Drag make-up represents a large portion of the baseline Hydrazine propulsion system, due to the large atmospheric drag forces associated with the low altitude orbit. Of the $890 \mathrm{~kg}$ of propellant, $650 \mathrm{~kg}$ was needed for drag makeup to maintain the spacecraft to within $\pm 1.25 \mathrm{~km}$ of the nominal $350 \mathrm{~km}$ orbit. The remaining 240 $\mathrm{kg}$ was needed for a controlled re-entry maneuver. The total spacecraft mass, including fuel, was $3620 \mathrm{~kg}$. The design mission life is 3.5 years.

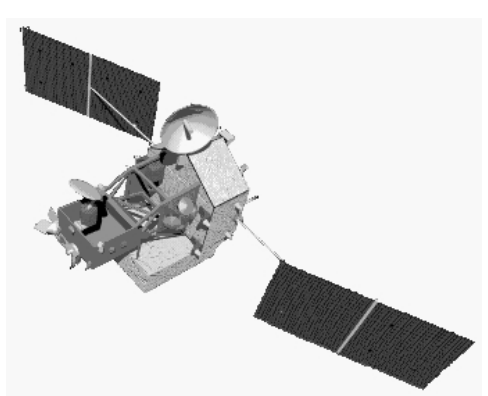

Figure 4. TRMM Satellite Concept

All the TRMM mission analyses were performed using a simple iterative routine to calculate orbit altitude change assuming constant drag force versus thrusting force over a circular orbit [9]. The propulsion analysis assumed a mission life average atmospheric density index of $150 \times 10^{-22}$ $\mathrm{W} / \mathrm{m}^{2}-\mathrm{Hz}$. The model did not account for daily atmospheric variations and assumed a constant $40 \%$ worst case solar eclipse during which no thrusting is performed.

A low power Hall propulsion system $(<1 \mathrm{~kW})$ is well suited to the drag makeup portion of the TRMM mission since only a small amount of thrusting and fuel is required every few days to maintain the operation orbit band. The drag makeup requirement based on the assumed atmospheric model was $0.5 \mathrm{~kg}$ of fuel every 6 or 8 days depending on the spacecraft cross-sectional area (which is influenced by the solar array technology). Additional solar array power is needed to operate thrusters during drag make-up burns since the payload is assumed to be using all of the bus power. The additional drag caused by the larger array is accounted for in the analysis.

The power and propulsion system analysis results for TRMM are presented in Figure 5. The bar chart shows the incremental benefits of either advanced power or electric propulsion, and then the combined benefits of both as compared to the SOA. The balance of spacecraft (Bal of $\mathrm{S} / \mathrm{C}$ ) represents the portion of spacecraft that is neither power or propulsion. It can also be considered as the spacecraft's gross payload. The baseline power and propulsion systems result in a balance of spacecraft of 2332 $\mathrm{kg}$. The propulsion mass includes thrusters, propellant, tankage, and any associated components, such as feed systems and power processing units.

The use of Hall effect thrusters for orbit maintenance in the "Adv Prop" case resulted in a $557 \mathrm{~kg}$ reduction in the 
overall propulsion system mass and a $19 \%$ increase in the balance of spacecraft. The drag make-up, thruster power was satisfied by adding an extra 1000 watts of solar array power. The total, revised solar array power of $5.0 \mathrm{~kW}$ BOL was sufficient to support the larger payload and the electric propulsion system, and corresponded to an increase in the power system mass to $435 \mathrm{~kg}$.

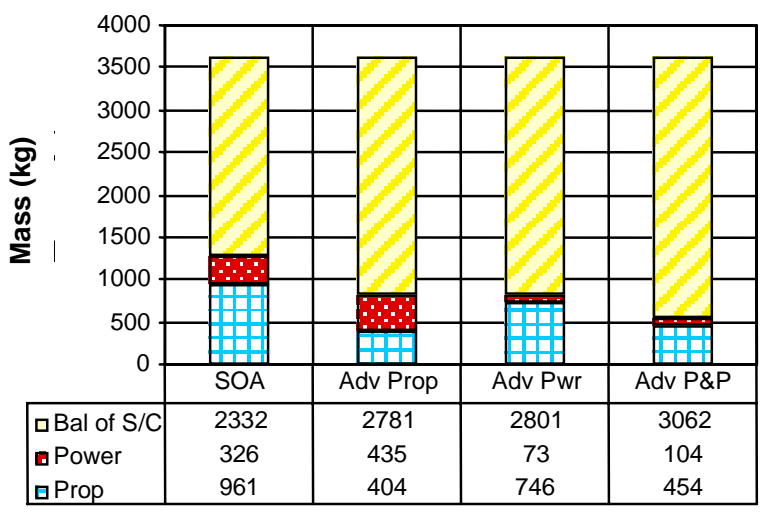

Figure 5. TRMM Performance Summary

Substituting four-junction solar arrays and flywheels for the baseline power system in the "Adv Pwr" option results in a $20 \%$ mass increase in the balance of spacecraft. The use of the high efficiency solar arrays and flywheels had a twofold impact on the spacecraft performance. First, the reduction in solar array area caused the orbit drag make-up fuel to decrease by $30 \%$. Second, the solar array power was reduced to $2.7 \mathrm{~kW}$ BOL, despite an increase in bus power to accommodate the larger payload. This was predominantly the result of a decrease in the recharging power for the higher efficiency flywheels as compared to the baseline NiCd batteries.

The balance of spacecraft increased to $3062 \mathrm{~kg}$, a $31 \%$ improvement over the baseline, with both advanced power and electric propulsion ("Adv P\&P"). A portion of the maximum potential increase was apportioned for additional propellant to extend the mission life to 7 years. The final spacecraft design included a $4.3 \mathrm{~kW}$ BOL four-junction solar array, $850 \mathrm{Whr}$ of flywheel energy storage, and a Hall effect propulsion system for orbit maintenance. The $4.3 \mathrm{~kW}$ array included an extra 800 watts, specifically allocated for executing the drag make-up maneuver. The end-of-life (EOL) bus power increased proportionally from $1.1 \mathrm{~kW}$ for the SOA design to $1.4 \mathrm{~kW}$ for the expanded payload.

\section{Globalstar}

Globalstar is a LEO based telecommunications satellite constellation consisting of 48 satellites at a $1414 \mathrm{~km}$ altitude [10]. A total of four Globalstar satellites are typically packaged within a Delta II 7925 launch vehicle. The baseline power system includes a $1.2 \mathrm{~kW}$ Si solar array and 280 Whr of $\mathrm{NiH}_{2}$ batteries designed to operate in the 79 minute sun/35 minute eclipse cycle. The power system is estimated to have a mass of about $120 \mathrm{~kg}$ (using the system model developed for these studies). An on-board hydrazine propulsion system, which provides final orbit insertion, repositioning, and de-orbiting accounts for $107 \mathrm{~kg}$ of spacecraft mass. The balance of the $450 \mathrm{~kg}$ baseline spacecraft, after power and propulsion, is $224 \mathrm{~kg}$ comprising the payload and other spacecraft systems.

The goal of the Globalstar analysis was to reduce the overall spacecraft mass to allow a greater number of satellites to be packaged within the Delta II launch vehicle. For each of the advanced power and propulsion cases, the balance of spacecraft was maintained at $224 \mathrm{~kg}$. The analytical results for the Globalstar case study are presented in Figure 6. Using $1.5 \mathrm{~kW}$ Hall thrusters in place of the hydrazine propulsion system in the "Adv Prop" case resulted in a total spacecraft mass of $382 \mathrm{~kg}$, a $15 \%$ reduction from the SOA. The electric propulsion option also permitted an increase in the launch vehicle delivered mass by assuming a greater portion of the orbit raising maneuver, and effectively decreasing the satellite drop-off altitude [11]. The mass savings for the "Adv Prop" case enabled the delivery of one extra satellite in the Delta II launch scenario.

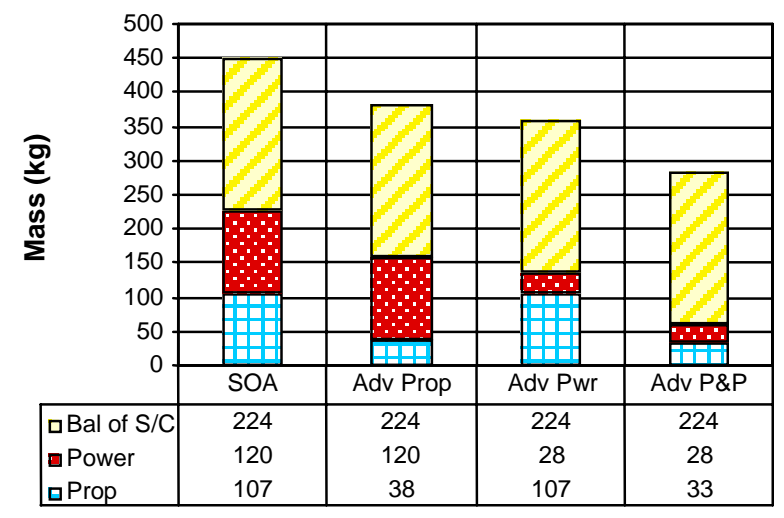

Figure 6. Globalstar Performance Summary

The "Adv Pwr" case assumed the use of high efficiency, four-junction solar arrays and flywheels. Overall power system mass was reduced from $120 \mathrm{~kg}$ to $28 \mathrm{~kg}$, which accompanied a decrease in the solar array area of $75 \%$. The total spacecraft mass for the advanced power case was $358 \mathrm{~kg}$, allowing one additional satellite in the Delta II launch vehicle.

The combination of advanced power and electric propulsion in the "Adv P\&P" case, resulted in a total spacecraft mass of $285 \mathrm{~kg}$. This represents a $165 \mathrm{~kg}$ mass savings over the SOA case. By performing a large portion of the orbit raising, the electric propulsion system enabled an increase in the launch vehicle delivered mass from $1800 \mathrm{~kg}$ to $2026 \mathrm{~kg}$. The drawback to the electric propulsion orbit raise is a 30 day transfer time to achieve final operating orbit. However, the advanced power and propulsion design allowed the delivery of seven satellites (based on mass) with the Delta II launch vehicle, effectively decreasing the number of launches to deploy the constellation from 12 to 7 . At approximately $\$ 50 \mathrm{M}$ per Delta II launch, the total launch 
cost savings would be $\$ 250 \mathrm{M}$. The impact of advanced power and electric propulsion is particularly dramatic for satellite constellations.

\section{SBIRS-High}

The SBIRS mission provides space-based military surveillance for missile warning, missile defense, and tactical intelligence [12]. The SBIRS-Low component is a passive sensing system intended to acquire and track ballistic missiles. The SBIRS-High component consists of four GEO satellites and two Highly Elliptical Orbit (HEO) satellites which would effectively replace the present Defense Support Program (DSP) satellite system. The GEO based, SBIRSHigh satellite is the subject of this analysis. Because of the sensitive nature of the SBIRS mission, only a minimal amount of satellite design information was available. Much of the design requirements and baseline power and propulsion technologies were inferred based on notional concepts. An Atlas IIAS launch vehicle is assumed to deliver the $3685 \mathrm{~kg}$ spacecraft to a geosynchronous transfer orbit (GTO). An onboard chemical system then performs an apogee maneuver to insert the spacecraft into GEO.

The baseline power system for SBIRS-High is estimated to provide a nominal bus power of $5 \mathrm{~kW}$ EOL, and must operate through the 24 hour GEO orbit period with eclipse periods lasting up to 70 minutes. Figure 7 presents the performance summary for the SBIRS-High mission. The SOA power system includes a $6.5 \mathrm{~kW}$ BOL GaAs solar array and $5.8 \mathrm{~kW}$-hrs of $\mathrm{NiH}_{2}$ batteries, accounting for 465 $\mathrm{kg}$ of the total spacecraft mass. The baseline propulsion technology is assumed to be a bi-prop system providing GTO-to-GEO orbit transfer, stationkeeping, and satellite repositioning. The propulsion system and fuel comprise the majority of the spacecraft at $62 \%$. The quantity of propellant for the SOA propulsion system is sufficient for 10 years of stationkeeping and up to ten, $90^{\circ}$ orbital repositions with 14 day transfer times. The SOA power and propulsion systems result in a balance of spacecraft of $940 \mathrm{~kg}$, available for the payload and remaining spacecraft systems.

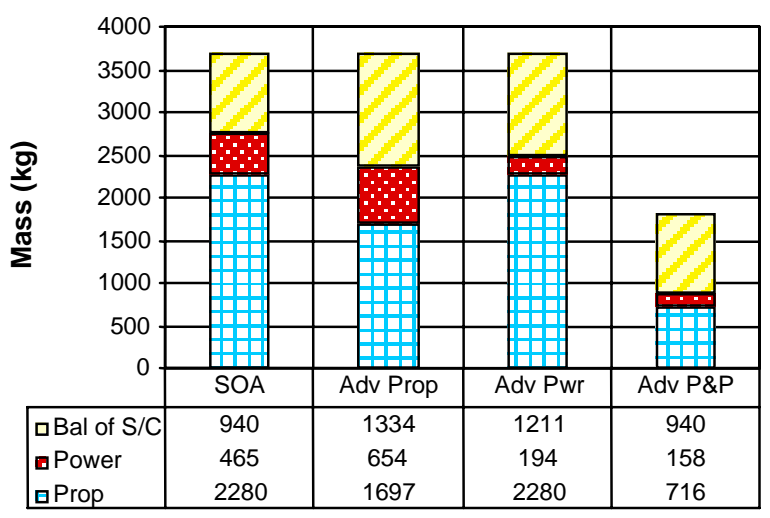

Figure 7. SBIRS-High Performance Summary
Hall effect thrusters can potentially perform stationkeeping, repositioning, and a portion of the orbit insertion; each maneuver requiring distinctly different operating approaches [13]. NSSK is performed by daily thruster firings (up to several hours in duration) about the orbit nodes (where the orbit plane crosses the equator). Repositions are executed by raising or lowering the spacecraft to a phasing orbit and then returning to GEO at the desired location. Orbit insertion is accomplished by offloading chemical apogee propellant and starting the Hall thruster operation from an inclined, highly elliptic orbit. The Hall thrusters then burn continuously to raise perigee, lower apogee, and change plane to insert the spacecraft into GEO.

If $5 \mathrm{~kW}$ class Hall effect propulsion is substituted to provide stationkeeping and repositioning, the balance of spacecraft mass increases to $1334 \mathrm{~kg}$ as shown in the "Adv Prop" case. This $42 \%$ growth accompanies an increase in the EOL bus power to $7 \mathrm{~kW}$ and solar array power to $9.2 \mathrm{~kW}$ to accommodate the larger payload. A variation on the "Adv Prop" case could utilize the mass savings for propellant to expand spacecraft operations. The additional propellant would permit 15 years of stationkeeping and forty-five $90^{\circ}$ repositions with 9 day transfer times while maintaining the $940 \mathrm{~kg}$ gross payload. These capabilities are significantly better than the SOA case with 5 additional years of stationkeeping, over $4 \mathrm{x}$ the number of repositions, and a $35 \%$ decrease in the reposition transfer time.

The "Adv Pwr" case offers a moderate 29\% improvement in balance of spacecraft, from $940 \mathrm{~kg}$ to $1211 \mathrm{~kg}$. This was achieved by replacing the GaAs arrays and $\mathrm{NiH}_{2}$ batteries with four-junction solar arrays and Li-polymer batteries. Despite increases in the EOL bus power to $6.2 \mathrm{~kW}$ and the BOL array power to $7.7 \mathrm{~kW}$, the power system mass was reduced by $58 \%$ relative to the SOA case.

The objective of the "Adv P\&P" case was to provide a launch vehicle class reduction while expanding on-orbit operations using electric propulsion. A Delta II 7925 launch vehicle, delivering $1815 \mathrm{~kg}$ to GTO, is used in place of the Atlas IIAS. This scenario would maintain the $940 \mathrm{~kg}$ balance of spacecraft calculated for the SOA case. The advanced power system satisfies the baseline power requirements while reducing mass by $66 \%$ over the SOA. The Hall effect propulsion system is used for NSSK, repositions and a 50 day orbit insertion from a highly elliptic orbit. Sufficient propellant is included for 15 years of stationkeeping and ten $90^{\circ}$ repositions with 9 day transfer times. The launch cost savings with the Delta II, allocated to the four GEO satellites needed for SBIRS-High, would be approximately $\$ 200 \mathrm{M}$. Alternatively, two of the smaller spacecraft using advanced power and propulsion technologies could be packaged in one Atlas IIAS launch vehicle (based on mass), eliminating the need for two of the four launches. 


\section{Mercury Orbiter}

The Mercury Orbiter mission, shown pictorially in Figure 8, is being considered as one of several promising NASA missions under the "Sun-Earth Connection" science theme [14]. The orbiter payload is expected to require about 300 watts of power and $450 \mathrm{Whr}$ of energy storage for science instruments and communications. The high temperature, high insolation Mercury environment introduces numerous design complications for the power system. The high energy planetary trajectory is similarly difficult for the propulsion system. A Delta III launch vehicle was assumed to deliver the SOA $1825 \mathrm{~kg}$ spacecraft to an Earth escape trajectory.

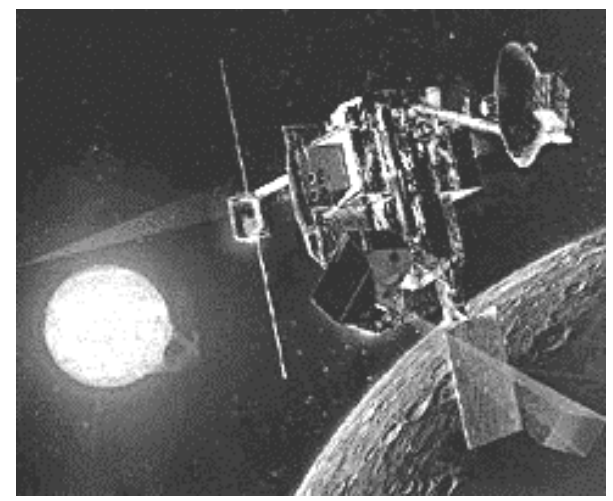

Figure 8. Mercury Orbiter Concept

Figure 9 summarizes the results of the power and propulsion study for Mercury Orbiter. The SOA power technologies were selected to be GaAs arrays and $\mathrm{NiH}_{2}$ batteries at a total mass of $54 \mathrm{~kg}$. The propulsion technology is assumed to be a bi-prop system, which is supplemented by a total of four gravity assists, two at Venus and two at Mercury. The chemical propulsion system represents the majority of the spacecraft comprising $68 \%$ of the total. Total trip time was determined to be 4.2 years. The SOA case resulted in a balance of spacecraft mass of $540 \mathrm{~kg}$ available for the orbiter payload and support systems.

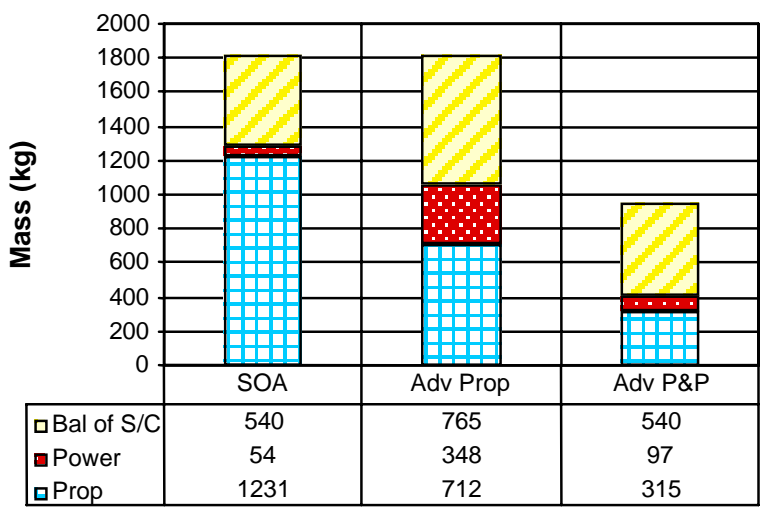

Figure 9. Mercury Orbiter Performance Summary

The baseline 420 watt BOL solar array was not sufficient to make electric propulsion a viable option. Therefore, the power system was augmented with additional solar array area. In the "Adv Prop" case, the added solar array power was iterated until the total spacecraft mass matched the SOA value. A $7.8 \mathrm{~kW}$ GaAs solar array resulted in an increase in the power system mass to $348 \mathrm{~kg}$. However, the power system mass increase was more than offset by the savings realized with Ion electric propulsion. The 3600 second Isp, $65 \%$ efficient Ion propulsion system required about $557 \mathrm{~kg}$ less fuel than the chemical system and needed only one Venus gravity assist. The advanced propulsion option yielded an increase in the balance of spacecraft to $765 \mathrm{~kg}$ and a reduction in the trip time to 2.7 years.

Considerable cost savings would be possible if the Delta III could be replaced by a smaller launch vehicle. The "Adv P\&P" case attempted to package the Mercury Orbiter spacecraft within a Delta II 7925 having a $952 \mathrm{~kg}$ Earth escape mass capability. With this option, the balance of spacecraft was held to the SOA value of $540 \mathrm{~kg}$ and the trip time was maintained at 2.7 years. Four-junction solar arrays and Li-polymer batteries were chosen to replace the baseline systems. The array power was varied until the spacecraft satisfied the Delta II mass constraint. This culminated in a BOL array power of $5.4 \mathrm{~kW}$ and a power system mass of $97 \mathrm{~kg}$. An advanced 4600 second, $70 \%$ overall efficient Ion propulsion was needed to achieve the launch vehicle stepdown. The required propellant to deliver the Mercury Orbiter with the Ion propulsion system was $222 \mathrm{~kg}$, an $80 \%$ decrease from the SOA chemical system. The advanced power and propulsion case delivered the orbiter payload to Mercury while saving an estimated $\$ 40 \mathrm{M}$ in launch costs and 1.5 years in trip time.

\section{CONCLUSIONS}

A series of mission case studies were used to quantify the impact of advanced power and electric propulsion technologies. These missions were chosen to provide a diversity of requirements and represent many of the potential applications for power and propulsion systems. The studies examined the separate benefits of either advanced power or electric propulsion, and then the combined benefits possible when the two systems were considered together. The relationship of lightweight power systems and high specific impulse electric propulsion was found to be synergistic, providing dramatic mass savings over the state-of-the-art. The impact of combining advanced power and electric propulsion was also greater than the sum of the contributions provided by either power or propulsion separately. The mass savings were applied to achieve a myriad of spacecraft improvements including increased payload, longer life, expanded operations, and/or launch vehicle class reductions.

A summary of the mission case studies is provided in Table 4. The LEO based TRMM mission showed that advanced power and electric propulsion could be combined to provide a 30\% increase in gross payload and extend the mission life by a factor of two. The combination of a higher efficiency solar array and flywheel energy storage accounted for a 
considerable decrease in the spacecraft drag area and a corresponding reduction in the orbit maintenance propellant. The Globalstar constellation could benefit by the use of advanced power and electric propulsion by reducing the mass of an individual satellite by almost $40 \%$. This allowed three more satellites, a total of seven, to be delivered with the Delta II launch vehicle effectively reducing the number of launches required for the constellation by almost $50 \%$ and saving about $\$ 250 \mathrm{M}$ in launch costs. SBIRS-High, a GEO based military surveillance mission, was improved by advanced power and electric propulsion through a launch vehicle class step-down from Atlas to Delta and a considerable extension in operational capability. The life of the satellite was increased by 5 years with additional stationkeeping fuel and the reposition transfer time was improved by $35 \%$ with the use of Hall effect thrusters. The launch cost savings resulting from the vehicle step-down amounted to approximately $\$ 200 \mathrm{M}$ for the four satellite deployment. The final mission case study, Mercury Orbiter utilized advanced power and electric propulsion technology to drop a launch vehicle class and improve trip time. An $80 \%$ reduction in propellant (and three fewer gravity assists) allowed the Mercury spacecraft to be launched by a Delta II rather than a Delta III, accounting for about $\$ 40 \mathrm{M}$ in launch cost savings. The Ion propulsion system also resulted in a decrease in the Earth-to-Mercury transit time of 1.5 years as compared to the baseline chemical system.

Table 4. Mission Results Summary

\begin{tabular}{|c|c|c|c|}
\hline Mission & $\mathrm{SOA}$ & Advanced & Overall Benefit \\
\hline TRMM & $\begin{array}{l}\text { GaAs/NiCd } \\
\text { Mono-Prop }\end{array}$ & $\begin{array}{l}\text { 4J MBG/FW } \\
<1 \mathrm{~kW} \text { Hall } \\
\text { Effect }\end{array}$ & $\begin{array}{c}30 \% \text { payload } \\
\text { increase, } 30 \% \\
\text { less drag make- } \\
\text { up fuel, } 2 x \text { life }\end{array}$ \\
\hline Globalstar & $\begin{array}{c}\mathrm{Si} / \mathrm{NiH}_{2} \\
\text { Mono-Prop }\end{array}$ & $\begin{array}{l}\text { 4J MBG/FW } \\
1.5 \mathrm{~kW} \text { Hall } \\
\text { Effect }\end{array}$ & $\begin{array}{c}40 \% \text { s/c mass } \\
\text { reduction, } 3 \\
\text { more s/c per } \\
\text { launch, } 50 \% \\
\text { fewer launches }\end{array}$ \\
\hline $\begin{array}{l}\text { SBIRS- } \\
\text { High }\end{array}$ & $\begin{array}{c}\mathrm{GaAs} / \mathrm{NiH}_{2} \\
\text { Bi-Prop }\end{array}$ & $\begin{array}{l}\text { 4J MBG/Li P } \\
\sim 5 \mathrm{~kW} \text { Hall } \\
\text { Effect }\end{array}$ & $\begin{array}{c}\text { LV class } \\
\text { stepdown, } 5 \text { yr } \\
\text { life extension, } \\
35 \% \text { faster } \\
\text { repos. time }\end{array}$ \\
\hline $\begin{array}{l}\text { Mercury } \\
\text { Orbiter }\end{array}$ & $\begin{array}{c}\mathrm{GaAs} \mathrm{NiH}_{2} \\
\text { Bi-Prop } \\
\text { (4 Grav. } \\
\text { Assists) } \\
\end{array}$ & $\begin{array}{l}\text { 4J MBG/Li P } \\
\text { 5 kW Ion } \\
\text { (1 Grav. } \\
\text { Assist) }\end{array}$ & $\begin{array}{c}\text { LV class } \\
\text { stepdown, } 80 \% \\
\text { fuel reduction, } \\
1.5 \text { yr trip time } \\
\text { savings }\end{array}$ \\
\hline
\end{tabular}

\section{REFERENCES}

[1] Landis, G.A., Bailey, S.G., and Piszczor, M.F., "Recent Advances in Solar Cell Technology," Journal of Propulsion and Power, Vol. 12, Number 5, pp. 835-841, 1996.

[2] Spence, B., et al, "The SCARLET Array for High Power GEO Satellites," $26^{\text {th }}$ IEEE Photovoltaic Specialists Conference, September, 1997.
[3] Cole, J.H., Eskra, M., Klein, M., "Bipolar Nickel-Metal Hydride Batteries for Aerospace Applications," $34^{\text {th }}$ Intersociety Energy Conversion Engineering Conference, August, 1999, IECEC-1999-01-2488.

[4] Teofilo, V.L., et al, "Advanced Lithium Ion Solid Polymer Electrolyte Battery Development," $34^{\text {th }}$ Intersociety Energy Conversion Engineering Conference, August, 1999, IECEC-1999-01-2463.

[5] Christopher, D.A., and Donet, C., "Flywheel Technology and Potential Benefits for Aerospace Applications," IEEE Aerospace Conference, March, 1998.

[6] Rawlin, V.K., et al, "An Ion Propulsion System for NASA's Deep Space Missions," AIAA Space Technology Conference, September, 1999, AIAA-99-4612.

[7] Garkusha, V., et al, "Modern Status of Hall Thruster Development in Russia," $35^{\text {th }}$ Joint Propulsion Conference, June, 1999, AIAA-99-2157.

[8] Moran, V.E., et al, "Design and Early In Flight Performance of the Tropical Rainfall Measuring Mission (TRMM) Power System," $33^{\text {rd }}$ Intersociety Energy Conversion Engineering Conference, August, 1998, IECEC98-285.

[9] Oleson, S.R., Hamley, J., Sankovic, J.M., Sample Mission Applications of Capacitor Powered Hall Thrusters, $33^{\text {rd }}$ Joint Propulsion Conference, July, 1997, AIAA-972785 .

[10] Space Systems/Loral Company Website, http://www.ssloral.com/ssl/heritage/datashts/gblstar.pdf, 1999.

[11] Oleson, S.R, Electric Propulsion for Low Earth Orbit Communication Satellites, $25^{\text {th }}$ International Electric Propulsion Conference, August, 1997, IEPC 97-148.

[12] United States Air Force Website, Space-Based Infrared System Fact Sheet, http://www.laafb.af.mil/SMC/PA/ Fact_Sheets/sbirs_fs.htm, 1999.

[13] Oleson S.R., et al, "Advanced Propulsion for Geostationary Orbit Insertion and North-South Station Keeping," Journal of Spacecraft and Rockets, Vol. 34, Number 1, pp. 22-28, 1997.

[14] Bennett, R., and Rowley, B., "Combined Mercury Orbiter," Advanced Projects Design Team, Team X Final Report, January - March, 1997. 
Lee Mason is a Senior Power System Engineer in the Power and On-Board Propulsion Technology Division at Glenn Research Center. He has been involved in both testing and analysis of advanced power technologies for more than 12 years, and has authored over 40 technical papers. He acquired a BSME from the University of Dayton in 1987 and a MSME from Cleveland State University in 1996.
Steve Oleson is a Lead Propulsion Analyst in the Power and Propulsion Office at GRC. He has 14 years experience projecting, analyzing, testing and developing advanced spacecraft propulsion systems and upper stages and has authored over 30 technical publications on these topics. He received a BSME from Ohio Northern University in 1986 and a M.S. in Astronautical Engineering from the Air Force Institute of Technology in 1990. 


\begin{tabular}{|c|c|}
\hline \multicolumn{2}{|c|}{ REPORT DOCUMENTATION PAGE } \\
\hline \multicolumn{2}{|c|}{$\begin{array}{l}\text { Public reporting burden for this collection of information is estimated to average } 1 \text { hour per response, including the time for reviewing instructions, searching existing data sources, } \\
\text { gathering and maintaining the data needed, and completing and reviewing the collection of information. Send comments regarding this burden estimate or any other aspect of this } \\
\text { collection of information, including suggestions for reducing this burden, to Washington Headquarters Services, Directorate for Information Operations and Reports, } 1215 \text { Jefferson } \\
\text { Davis Highway, Suite 1204, Arlington, VA 22202-4302, and to the Office of Management and Budget, Paperwork Reduction Project (0704-0188), Washington, DC 20503. }\end{array}$} \\
\hline 1. AGENCY USE ONLY (Leave blank) & \begin{tabular}{|c|c|} 
2. REPORT DATE & 3. \\
March 2000 &
\end{tabular} \\
\hline $\begin{array}{l}\text { 4. TITLE AND SUBTITLE } \\
\text { Spacecraft Impacts with Ad }\end{array}$ & Spacecraft Impacts with Advanced Power and Electric Propulsion \\
\hline \multicolumn{2}{|c|}{ Lee S. Mason and Steven R. Oleson } \\
\hline $\begin{array}{l}\text { 9. SPONSORING/MONITORING AGEI } \\
\text { National Aeronautics and Sp } \\
\text { Washington, DC 20546-00 }\end{array}$ & $\begin{array}{l}\text { NAME(S) AND ADDRESS(ES) } \\
\text { Administration }\end{array}$ \\
\hline
\end{tabular}

Prepared for the 2000 Aerospace Conference sponsored by the Institute of Electrical and Electronics Engineers, Big Sky, Montana, March 18-25, 2000. Responsible person, Lee S. Mason, organization code 5490, (216) 977-7106.

\begin{tabular}{|l|l|}
\hline 12a. DISTRIBUTION/AVAILABILITY STATEMENT & 12b. DISTRIBUTION CODE
\end{tabular}

Unclassified - Unlimited

Subject Categories: 18 and $20 \quad$ Distribution: Nonstandard

This publication is available from the NASA Center for AeroSpace Information, (301) 621-0390.

\section{ABSTRACT (Maximum 200 words)}

A study was performed to assess the benefits of advanced power and electric propulsion systems for various space missions. Advanced power technologies that were considered included multiband gap and thin-film solar arrays, lithium batteries, and flywheels. Electric propulsion options included Hall effect thrusters and Ion thrusters. Several mission case studies were selected as representative of future applications for advanced power and propulsion systems. These included a low altitude Earth science satellite, a LEO communications constellation, a GEO military surveillance satellite, and a Mercury planetary mission. The study process entailed identification of overall mission performance using state-of-the-art power and propulsion technology, enhancements made possible with either power or electric propulsion advances individually, and the collective benefits realized when advanced power and electric propulsion are combined. Impacts to the overall spacecraft included increased payload, longer operational life, expanded operations and launch vehicle class step-downs.

14. SUBJECT TERMS 15. NUMBER OF PAGES

Space power; Electric propulsion; Solar arrays; Batteries 16

Space power, Electric propulsion; Solar arrays, Batteries

\begin{tabular}{|c|c|}
\hline $\begin{array}{c}\text { 17. SECURITY CLASSIFICATION } \\
\text { OF REPORT } \\
\text { Unclassified }\end{array}$ & $\begin{array}{c}\text { 18. SECURITY CLASSIFICATION } \\
\text { OF THIS PAGE } \\
\text { Unclassified }\end{array}$ \\
\hline
\end{tabular}

19. SECURITY CLASSIFICATION
OF ABSTRACT
Unclassified

Standard Form 298 (Rev. 2-89)

Prescribed by ANSI Std. Z39-18 298-102 